\title{
Péntek, János and Benö, Attila, 2020. A Magyar Nyelv Romániában (Erdélyben) ['The Hungarian Language in Romania (in Transylvania)']. Ed. Miklós Kontra. Kolozsvár and Budapest: Erdélyi Múzeum-Egyesület (EME) and Gondolat Kiadó.
}

\author{
Reviewed by Siarl Ferdinand, University of Wales Trinity Saint David \\ yeth_kernewek@yahoo.co.uk
}

The Hungarian language has been spoken in the area that is known as Transylvania since, at least, the arrival of the Magyars led by Árpád in the ninth century A.D. In fact, despite Transylvania's turbulent history, its mixed ethnic composition and its traditional linguistic diversity, Hungarian continues to be both the second most spoken non-foreign language of Romania, and the majority language in some of its counties and towns. A Magyar Nyelv Romániában (Erdélyben) ['The Hungarian Language in Romania (in Transylvania)'] is a volume designed to offer a detailed summary on the current state of the Hungarian language in Transylvania, where the overwhelming majority of the Hungarian speakers in Romania are concentrated. The information contained in this volume goes beyond the traditional comparison between majority and minority languages, in this case Romanian and Hungarian. Here the authors present detailed analyses of the factors that shape the use of Hungarian, which include a very interesting perspective of the Hungarian varieties spoken in Transylvania and how they sometimes differ from standard Hungarian. This approach allows the reader to see the Hungarian speakers of Transylvania not as a figurative buffer zone between two states, but as a community with its own cultural idiosyncrasies and unique struggle: to be regarded not as an appendix of others but as a fully developed community. The findings in this book are the fruit of a broad range of empirical investigations. These findings and other data are illustrated in maps, graphs and tables. The volume itself is part of a larger project led by Miklós Kontra and aimed to study the state of the Hungarian language in the Carpathian Basin. The two authors of the present volume, János Péntek and Attila Benő, are professors of Hungarian linguistics at Babeş-Bolyai University in Kolozsvár/Cluj-Napoca. Both of them are highly acclaimed academics in the fields of sociolinguistics, language contact and Hungarian dialectology.

Although Romania is far from a monolingual country, Romanian is the only official language at all levels of the country's education system. Besides Romanian, the list of languages spoken by noticeable minorities includes Hungarian, Romani, German, Tatar, Turkish, Ukrainian, Russian and more. The situation of these languages also differs greatly, so that while most are spoken by relatively small communities in a few villages or by minorities all over the country, such as Romani, Hungarian is spoken by more than one million people (of the country's almost twenty million people), and most of them are concentrated in northern Transylvania. Hungarian speakers, including mostly Szeklers or Székelyek and Magyars, but also Csángós,

(cc) BY

ULLS D-Serle 
Ferdinand, Siarl. "Péntek, János and Benő, Attila, 2020. A Magyar Nyelv Romániában (Erdélyben) ['The Hungarian Language in Romania (in Transylvania)']. Ed. Miklós Kontra. Kolozsvár and Budapest: Erdélyi Múzeum-Egyesület (EME) and Gondolat Kiadó." Hungarian Cultural Studies. e-Journal of the American Hungarian Educators Association, Volume 14 (2021) DOI: 10.5195/ahea.2021.443

Roma (also called Gypsies), Jews and other ethnicities, constitute clear majorities in two counties and tens of localities, and large minorities in many other places. According to old traditions, the Hungarian language was brought to the region by the Hun invaders, of whom the Szeklers are considered as the modern descendants. Nowadays, most researchers think that Hungarian arrived with Árpád's people during the ninth century. From that time until the twentieth century, Transylvania was considered one of the provinces of the Hungarian Kingdom. All this changed when Hungary was forced to lose this region to Romania, first after World War I, and then again after World War II. Although the region's ethnic/linguistic composition has changed notably following these geo-political changes, it has never ceased to be a melting pot of languages, religions and nationalities. Therefore, the present volume focuses on the usage of Hungarian in the region from a number of interlinked perspectives, including historical, social, economic, cultural and political.

The book at hand is structured in eight chapters that may be divided into four main parts. The first part, including the first three chapters, provides an extensive analysis of the Hungarian language in present-day Romania from a historical perspective, which serves as a basis for the rest of the work. The second part, consisting of Chapters Four and Five, deals with the current attitude of the Romanian authorities towards Hungarian and how this language is used in key domains such as education and the media. The policies and language usages described in these chapters link with the topics of Chapters Six and Seven, the third part of the volume. Here the authors provide an overview of how Hungarian is used by its Transylvanian speakers and they offer a very illuminating description of the Transylvanian dialects, based on fieldwork carried out in the area in the late 1990s. The volume's fourth and final part, namely Chapter Eight, summarizes the findings of the study as a whole, which then leads to a short analysis of the probable future of the Hungarian language in the region.

In the first, introductory chapter, the authors provide a detailed historical survey of the language situation of Transylvania from the Middle Ages to our days. They argue that a balance that existed for centuries was broken by war atrocities and intolerant, homogenizing national ideologies, and that this balance was considerably disrupted throughout the twentieth century. In their opinion, these same tendencies continued after the regime change around 1990 in Romania as in the entire Soviet Bloc. A very interesting feature of this chapter is the help of visual aids, such as maps showing how the ethnic composition of the region has changed over the centuries. The second chapter is devoted to the situation of the inclusive Hungarian-speaking communities of Romania, including Magyars, Szeklers, Csángós and Hungarian-speaking Roma and Jews. The first half of the chapter deals with the number of individuals in each such community, the number of Hungarian speakers in it, the level of their education and their economic situation, all based on Romanian population censuses and other studies. The second half of this chapter analyzes the Hungarian language communities according to their perceived identity and level of assimilation into Romanian society. Chapter Three offers a very detailed historical description of the local Hungarian language, as spoken by the general population, including in technical and literary environments, as well as some examples of how Hungarian speakers would use Hungarian and Romanian in certain situations.

In the second part of the book, Chapter Four focuses on the language policies implemented in Romania based on the principle of "one country, one official language" (111). This imperative means that no other language besides Romanian can achieve an official status, not even within a local community where the non-Romanian language may be spoken by the 
Ferdinand, Siarl. "Péntek, János and Benő, Attila, 2020. A Magyar Nyelv Romániában (Erdélyben) ['The Hungarian Language in Romania (in Transylvania)']. Ed. Miklós Kontra. Kolozsvár and Budapest: Erdélyi Múzeum-Egyesület (EME) and Gondolat Kiadó." Hungarian Cultural Studies. e-Journal of the American Hungarian Educators Association, Volume 14 (2021) DOI: 10.5195/ahea.2021.443

majority. This conception of language and state produces negative consequences in fields such as economy, education and culture. The authors argue that the only way to balance this situation is by regional autonomy for the Hungarian-speaking communities of Romania. In Chapter Five the discussion of official policies is illustrated by facts about Hungarian language use in the region. In the field of education, for example, Hungarian students constitute a majority in a number of counties. However, it is accepted that in order to "have more opportunities in life," many Hungarian-speaking parents send their children to Romanian schools (179). The situation becomes less favorable for Hungarians as they grow up. This is illustrated by the fact that in 2011, 99.4 percent of the Hungarian children attended Hungarian schools, but only 78.2 percent attended Hungarian secondary schools, and 38.4 percent cursed their university studies in Hungarian (178). In this chapter, the authors also review the use of Hungarian in contexts such as theatre shows and performative arts in general, libraries and book production, religious life and the media. This chapter might be the least well-developed part of the volume due to its lack of some key statistics, such as the number of plays or films in Hungarian, or spectators by language, or the spread of literary works by language, the number of academic journals published in Hungarian, the number and degree of circulation of Hungarian newspapers and magazines, etc. In any case, the analysis proves that Hungarian culture in Transylvania is alive and has even notably improved its situation after 1990.

Part Three, encompassing Chapters Six and Seven, deals specifically with how individuals, rather than institutions, use Hungarian and other languages. Chapter Six introduces the topic by showing how the knowledge of Hungarian and at least basic Romanian is widely extended among those who identify themselves as members of the Hungarian community. Moreover, local Hungarian dialects enjoy high prestige among their speakers. Chapter Seven is one of the most interesting ones in this study. After an introduction to the situation of language contact and its consequences, the authors provide a very detailed description of the dialects spoken in Transylvania. This account is followed by a description of the effects of RomanianHungarian contact on the local Hungarian variants. Based on a study carried out in 1996, the chapter continues with some examples of differences between Transylvanian Hungarian and standard Hungarian deriving from various factors, such as religious affiliation or place of birth. Since it would be totally impossible to comment on all the findings of the 1996 study in just a few pages, the authors have included all of its results in the appendix starting on page 379, itself a masterpiece of Hungarian dialectology.

In Chapter Eight the authors conclude that the stressful political periods of the twentieth century have contributed to the weakening of people's awareness of their legal language rights. Moreover, they state that some political measures to support the use of Hungarian do not have any benefit for the community of speakers since they are not based on professional studies. For this reason and in order to stop the decline of the Hungarian speaking community, Péntek and Benö advocate for a better organized language planning in which all the subgroups of speakers, such as Hungarians and Roma, must be considered. They underline that within this context, education must have a prominent place, since it assures that those who were already born into the Hungarian community might actually choose to remain in it (345).

A Magyar Nyelv Romániában (Erdélyben) is a key work in that it presents an accurate and updated overview of the situation of the Hungarian language in Transylvania. The reading in this volume is smooth, although some sociolinguistic background is advisable. The wellstructured chapters and their division into smaller sections and the many maps, graphs and tables 
Ferdinand, Siarl. "Péntek, János and Benő, Attila, 2020. A Magyar Nyelv Romániában (Erdélyben) ['The Hungarian Language in Romania (in Transylvania)']. Ed. Miklós Kontra. Kolozsvár and Budapest: Erdélyi Múzeum-Egyesület (EME) and Gondolat Kiadó." Hungarian Cultural Studies. e-Journal of the American Hungarian Educators Association, Volume 14 (2021) DOI: 10.5195/ahea.2021.443

illustrating the findings are of invaluable help. Still, some points, such as the parts dealing with the state of Hungarian in the arts and media, might have been more fully explained and supported by data. In all other respects, Péntek, Benő and Kontra deserve the highest commendation for having produced a volume that thoroughly explores one of the most interesting cases of language contact in Europe from both the strictly linguistic and the wider sociocultural perspectives. 